\title{
9. MICROSTRUCTURES IN SEMICONSOLIDATED SEDIMENTS OF DEEP SEA DRILLING PROJECT LEG 59 (PHILIPPINE SEA TRANSECT) AND THEIR RELATION TO REGIONAL TECTONIC SETTING
}

\author{
Pierre Chotin, ${ }^{1}$ Laboratoire de Géologie Structurale, Université Pierre et Marie Curie, \\ 75230 Paris Cedex 05, France
}

\section{INTRODUCTION}

The purpose of this study is to describe the occurrence of microstructures in Leg 59 sediments and to interpret the tectonic setting of back-arc regions of the Philippine Sea. Some 24 holes were drilled as part of the South Philippine Sea transect (Legs 59 and 60); the regions drilled include the West Philippine Sea, the PalauKyushu Ridge, the Parece Vela Basin, and the West Mariana Ridge on Leg 59 and the Mariana Trough, the Mariana arc, and the Mariana Trench on Leg 60. One of the key objectives of the South Philippine Sea transect was to test the hypothesis (Karig, 1971, 1975) that backarc basins and remnant arcs were progressively formed by processes of island-arc sundering that left remnant arcs on the west while the active portion of arcs migrated toward the east, creating marginal-basin spreading centers between them. Thus far, shipboard results of Legs 59 and 60 have supported this conclusion (Kroenke, Scott, et al., 1978; Hussong, Uyeda, et al., 1978), demonstrating progressively younger marginal basins from west to east. In particular, the Parece Vela Basin appears to be a classic case of symmetrical spreading that took place between the remnant PalauKyushu Ridge to the west and the active West Mariana Ridge to the east during the Oligocene and Miocene. Similarly, the West Mariana Ridge is now the remnant arc west of the modern Mariana Trough spreading center and the modern Mariana arc. A study of the microstructures in sediments from the remnant and active arcs will reflect the local stress environment and may reflect the regional tectonic environment at the time of deformation, as was assumed by Choukroune et al. (1978) in part of the FAMOUS project.

This study includes photographs and drawings of the microstructures on both hand-speciman and microscopic scales. The faults are observed in semiconsolidated chalks, vitric tuffs, and volcaniclastic breccias. Most of the sediments are well stratified and thinly bedded so that structures are easily seen. Any disruption of bedding because of drilling disturbances has been removed from this inventory.

Although the rock layers were oriented carefully before the cores were cut to show maximum or true dip of the beds, there is no orientation of the fault planes to insure that the maximum dip has been measured. There-

\footnotetext{
${ }^{1}$ Present address: Département de Géologie, Université Mohammed V, Rabat, Morocco.
}

fore all fault-plane dips are minimum values, and all the angles between sets of faults are maximum values.

\section{DESCRIPTION OF MICROSTRUCTURES}

\section{Site 448}

Sample 448-19,CC (19-28 cm) shows a reverse microfault in the upper part with a displacement of $2 \mathrm{~cm}$ to the right at an apparent dip of about $10^{\circ}$ (Plate 1, Fig. 1). Below that, another reverse microfault of opposite inclination affects about four layers with a displacement of 2 or $3 \mathrm{~mm}$. The top layer is not affected by the fault. This type of microfaulting is probably syndepositional and the result of internal sliding of the beds during turbiditic deposition.

In sample $448-21, C C(3-18 \mathrm{~cm})$, finely laminated vitric tuffs show a great number of normal microfaults, with displacements from 1 to $5 \mathrm{~mm}$ (Plate 1, Fig. 2). Direction of dip of the fault plane is from the top left to the bottom right. The whole section is affected by this phenomenon, which suggests postsedimentary tectonic movement.

Finely laminated homogeneous fine vitric tuffs with an even but narrowly spaced distribution of normal microfaults in Sample 448-25-1, 109-120 cm occur with 1 to $5 \mathrm{~mm}$ of throw (Plate 1, Fig. 3). These contain possible conjugate faults; if these two families of planes are conjugate, they indicate horizontal extension. The apparent $90^{\circ}$ angle between the two families of planes suggests that the coefficient of internal friction was low and the sediment poorly consolidated during faulting.

In Sample 448-29-1, 45-52 cm, two normal microfaults affect the upper beds of this tuff (Plate 1, Fig. 4). Displacement reaches $2 \mathrm{~mm}$.

The consolidated chalky tuff in Sample 448-35-1, $18-26 \mathrm{~cm}$ is cut by a fault from top right to bottom center and by numerous satellite microfaults from top left to bottom right (Plate 1, Fig. 5). This possible conjugate system may indicate postsedimentation horizontal extension. Note in the bottom left the normal displacement of a small white tuff pebble cut by two microfaults.

\section{Site $\mathbf{4 5 0}$}

In a vitric tuff in Sample 450-32-1, 15-29 cm, a microstructure resembles stylolites; however, it actually consists of open fractures filled by a calcitic cemented vitric tuff (Plate 1, Fig. 6). 


\section{Site 451}

In Sample 451-31-1, 55-60 cm, a dark foraminiferrich vitric tuff, the fault displacement is greater than the diameter of the sample (Plate 1, Fig. 7). The drag on the beds indicates normal faulting.

Sample 451-31,CC (14-22 cm), a clear example of possible conjugate faults, has up to $5 \mathrm{~cm}$ of displacement in alternating vitric tuffs and fine vitric tuffs (Plate 1, Fig. 8). On the left observe a vertical fault with satellite microfaults from top right to bottom left; and on the right, a possible conjugate system of faults, each dipping at $50^{\circ}$, which may indicate horizontal extension for this sample.

Figure 1A shows a full section of carbonate-rich vitric tuff (from Sample 451-42-1, 0-140 cm) with thin beds of black breccia cut by normal faults that may be conjugate and may indicate horizontal extension. Dip of layers is about $35^{\circ}$ to $40^{\circ}$; apparent dip of faults is about $60^{\circ}$ to $80^{\circ}$. Throw reaches $6 \mathrm{~cm}$.

Figure 1B illustrates Sample 451-46-2, 0-140 cm, a nonoriented full section of the same material as Core 42. Throw of faults is greater than in Core 42 and reaches $10 \mathrm{~cm}$. On top of this section, drag of material within the fault contact is observed.

Figure 2A presents Sample 451-60-2, 0-15 cm. These lithic and vitric volcaniclastic conglomerates and vitric tuffs are broken by a series of microfractures and some microfaults. This sample is thus complex and contains evidence of fracturing without displacement and open fractures filled with calcite.

The black vitric tuff and medium bluish gray volcaniclastic breccia in Sample 451-63-4, 70-81 cm is affected by a series of faults with an opposite dip direction relative to the dip of beds (Plate 1, Fig. 9). Possible conjugate smaller microfaults are seen between the two main faults of the sample. Fault drag has affected the coarse-grained material.

Figure $2 \mathrm{~B}$ pictures the tuffaceous volcaniclastic conglomerates of Sample 451-73-1, 0-40 cm, in which a normal fault has fault-gouge material and has reverse satellite microfaults. Although it is difficult to determine whether the major fault and the microfaults are related genetically, the microfaults seem to predate the major fault because they are cut by the major fault plane.

In a lithology similar to that pictured in Figure 2B, Figure 2C (Sample 451-73-1, 67-84 cm) shows reverse faults that occur at the top and normal syndepositional microfaults that occur at the base of the sample.

Sample $451-80-1,112-135 \mathrm{~cm}$ is a fine vitric tuff affected by a series of normal faults that join together on the top left (Fig. 2D). Throw is slight. Normal faulting and probable horizontal extension is thus evident for this section.

In conclusion, Leg 59 holes demonstrate these microstructures:

1) abundant normal microfaults with variable displacement and with steep dips, indicating that these faults probably affected consolidated sediment;
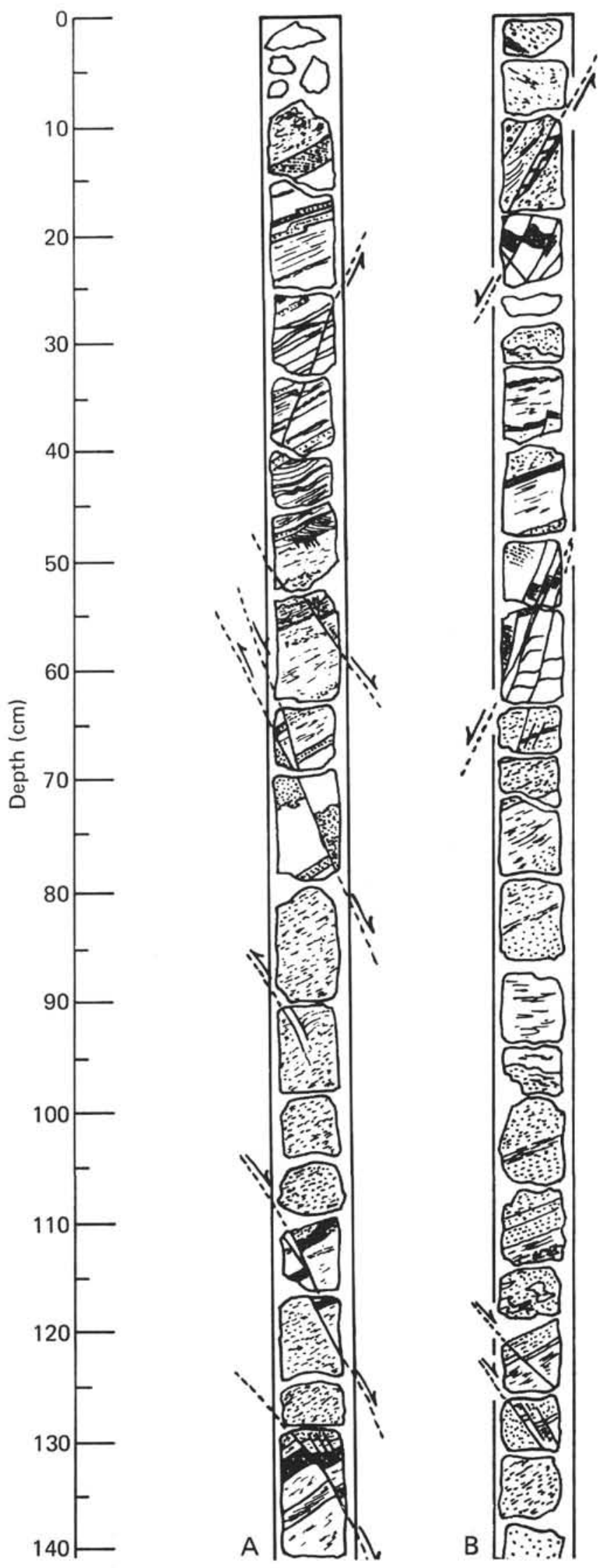

Figure 1. Microstructures in carbonate-rich vitric tuff (A: Sample 451-42-1; B: Sample 451-46-2). 


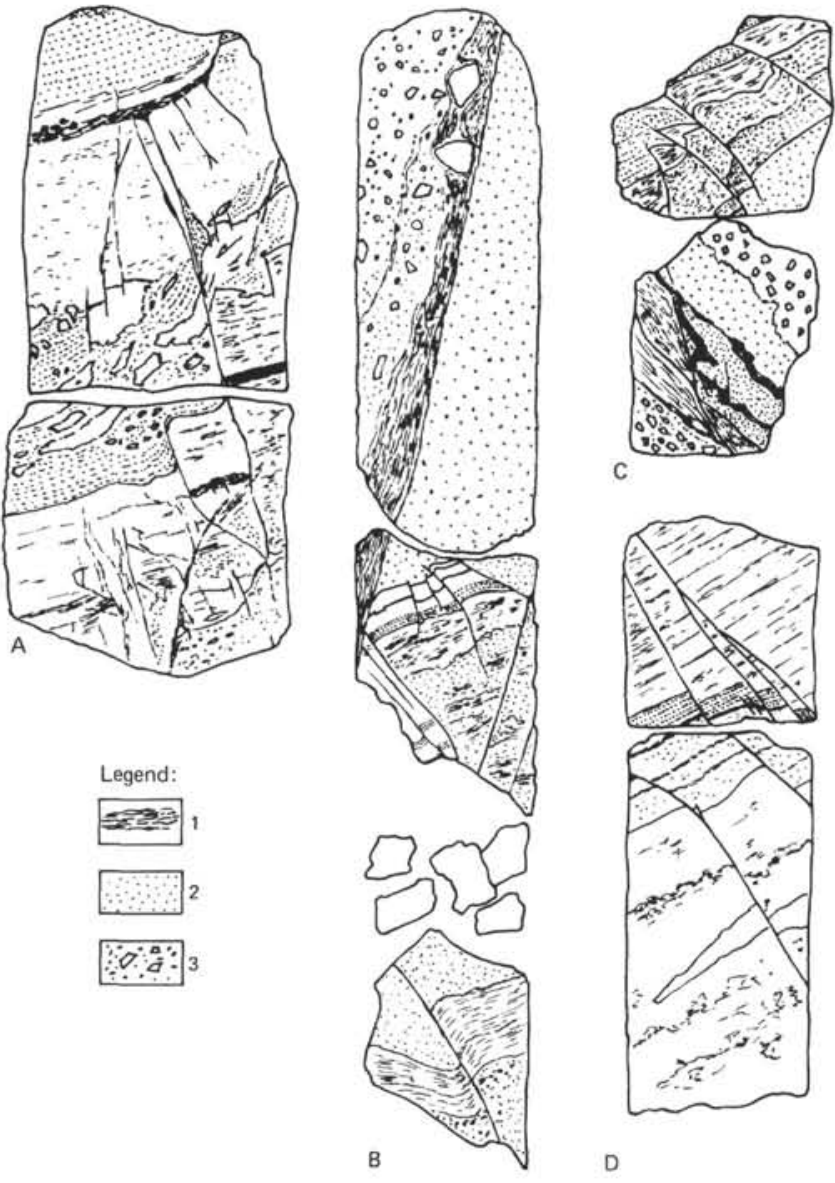

Figure 2. Details of microstructures in volcaniclastics from Hole 451. (A: Sample 451-60-2, 0-15 cm; B: Sample 451-73-1, 0-40 cm; C: Sample 451-73-1, 67-84 cm; and D: Sample 451-80-1, 112-135 cm. The legend designates 1 -fine vitric tuff, 2-vitric tuff, and 3 -coarse vitric tuff.)

2) some normal microfaults with lower dips, which may reflect syndepositional features if the fault planes are nearly normal to the cut surface;

3) some reverse microfaults, generally with small displacements; these may be caused by internal readjustment of sediments during turbiditic deposition. They may also be antithetic normal faults changed to reverse faults because of tilting on the main normal fault (Profett, 1977);

4) a few open fractures filled with calcite; and

5) some drag features along fault contacts.

Most of the faults affecting the sediments and basalts of the Philippine Sea system appear to be extensional features and can be compared with seismic-induced microfaults observed in the Pliocene basin of Santa Paula Creek (California) in turbiditic sequences (personal communication, R. Bourrouilh).

\section{OCCURRENCE OF MICROSTRUCTURES IN HOLES 447A, 448, 448A, 449, 450, AND 451}

During Leg 59, cores were studied to record the occurrence of faults in each hole. The size of the displacements and the apparent relative ages were also recorded.

Hole 447A was drilled on the eastern part of the West Philippine Basin between the Central Basin Ridge and the Palau-Kyushu Ridge; no microstructures were observed. The stratigraphic sequence consists of regular and unfractured lower middle Miocene pelagic clays that overlie middle to upper Oligocene sedimentary breccias. These older breccias suggest tectonic movements that were older than early Miocene and younger than the youngest breccia and thus probably date from the late Oligocene. Also, basement lavas at Hole 447A are cut by fractures; therefore the tectonic activity had to be local in part, as is suggested by the coarse cobblesized pieces of breccia in the overlying sedimentary section. It is possible that this region was affected by intermittent volcanic activity during the middle and late Oligocene, because the breccias are separated by ashrich horizons that represent periods of abundant volcanism. After the tectonic activity at Hole $447 \mathrm{~A}$ ceased, the region subsided below the carbonate compensation depth (post-late Oligocene). The cause of this local tectonic activity is not yet determined.

In Hole 448 the first occurrence of microfaults and soft-sediment deformation appears at the upper limit of lithification of the sediment (Core 19) in late Oligocene vitric tuffs and nannochalk (Sample 19,CC, 19-28). In these levels some reverse microfaults and syndepositional deformation features are observed, but normal faults are indeed the rule.

Below the sequence of the middle Oligocene vitric tuffs in Hole 448A, microfaults are more common (Samples 21,CC; 25-1; 31,CC, 35-1), with what appear to be extensional conjugate nets and millimeter to centimeter displacements. In the alternating layers of basalts and volcaniclastic breccias that form the lower part of the sequence, two features are noted: (1) the abundance of microfaults in breccia and tuffs increases downward, and (2) there is a rapid increase of the dip of the strata from $15^{\circ}$ to $45^{\circ}$.

The great accumulation of sediments during the Oligocene, the presence of abundant microstructures, and the progressive dip of the layers downward may suggest a general subsidence of the area of the PalauKyushu Ridge. These movements may have been caused by extensional faulting. Tilting must have occurred progressively during sedimentation, and most of the faulting occurred after consolidation.

The youngest beds clearly affected by normal faults on the Palau-Kyushu Ridge at Site 448 are of similar age as those at Site 447 (late Oligocene); however, the beds younger than late Oligocene on the ridge are poorly consolidated and do not have layering with which faulting can be recongized. Thus the time of deformation of the eastern side of the West Philippine Basin and the PalauKyushu Ridge may be the same (late Oligocene), but the age of deformation in the Palau-Kyushu Ridge cannot be specified unambiguously; it could be younger than late Oligocene, with undetected deformation in soft and massive featureless beds.

In Hole 449, located on the western part of the Parece Vela Basin, a sequence from the late Oligocene to the Pleistocene was encountered. There is no evidence of microstructures, but it is doubtful that the poorly consolidated and massive pelagic clays would record any. 
Hole 450 is located on the eastern part of the Parece Vela Basin. Within the 340 meters penetrated, very few microstructures were found in a monotonous sequence of clay, ash, and tuff. Nevertheless, the upper limit of the presence of normal and rare reverse microfaults indicates that they are younger than at western sites (middle Miocene); no older sediments than middle Miocene have been found. If the structures at the Palau-Kyushu Ridge in Site 448 can be assumed to have formed no later than late Oligocene, then the microstructures become younger toward the east.

In Hole 451, located on the eastern edge of the West Mariana Ridge, the best and most abundant examples of normal microfaults and some reverse faults were found. As at Site 448 , the reverse faults probably are not an indication of any regional mechanism of compression but of syndepositional deformation of sediments on an unstable ridge (Mattauer, 1973). The first well-displayed faults are reverse to the dip of strata (Plate 1). The faults dip at about $25^{\circ}$ to $30^{\circ}$ (apparent) and the strata at $45^{\circ}$ to $50^{\circ}$ in the opposite direction; displacement is large here and reaches some centimeters. The length of faults is in some cases greater than the length of section. Sample 31,CC shows a well displayed example of probable conjugate faults that indicate horizontal extension greater than $1 \mathrm{~cm}$.

\section{CONCLUSIONS}

In the western part of the South Philippine transect (Leg 59), extensional tectonics, suggested by regional subsidence and also by normal faults, seems to prevail. In the five sites studied in the Mariana arc system and also in Leg 60 sites (Hussong, Uyeda, et al., 1978) no indicators of compressional tectonics were found. This fits well with the theory of back-arc extension environments, as first proposed by Karig (1975). Moreover, the back-arc reconstruction models suggested by Kroenke, Scott, et al., (1978) in the Parece Vela Basin (Leg 59) and by Hussong, Uyeda, et al., (1978) in the Mariana Trough (Leg 60) show an extensional spreading mechanism for the opening of both the Parece Vela and Mariana marginal seas.

The tectonic expression of spreading thus comprises extensional features in the back-arc regions. From west to east, the microstructures seem to occur in progressively younger sediments, i.e., extensional microfaults probably occurred up to the upper Oligocene at Site 448, the middle Miocene at Site 450, and the middle to upper Miocene at Site 451 (Fig. 3). This suggests that there was a migration of the spreading mechanism of the back-arc Mariana system from west to east. Nevertheless, minor movements could have occurred in the western part of the system.

The results of Leg 60 in the eastern part of the South Philippine transect show evidence of extensional features (normal microstructures and subsidence). This correlates well with the migration of the arc oceanward and the opening of the back-arc regions. It will be very interesting to analyze this phenomenon by looking at the faulting in the trench and Pacific crust along the Marianas and also to compare the extensional features found in front of the Japan arc (von Huene, Nasu, et al., 1978).

\section{ACKNOWLEDGMENTS}

I thank A. Giret and J. Angelier of the University of Paris and R. Blanchet of the Universicy of Bretagne for help and suggestions and also for reading the manuscript; the Leg 59 team also provided helpful suggestions.

\section{REFERENCES}

Choukroune, P., Francheteau, J., and Le Pichon, X., 1978. In situ structural observations along Transform Fault A in the FAMOUS Area, Mid-Atlantic Ridge. Bull. Geol. Soc. Am., 89:1013-1029.

Hussong, D. M., Uyeda, S., et al., 1978. Tectonics of the Mariana Islands fore-arc region; results of DSDP Leg 60. Trans. Am. Geophys. Union, 59:1179. (Abstract)

Karig, D. E., 1971. Origin and development of marginal basins in the Western Pacific, J. Geophys. Res., 76:2542-2560. , 1975. Basin genesis in the Philippine Sea. In Karig, D. E., Ingle, J. C., Jr., et al., Init. Repts. DSDP, 31: Washington (U.S. Govt. Printing Office), 857-880.

Kroenke, L., Scott, R., et al., 1978. In the Philippine Sea: old problems answered, new ones asked. Geotimes, 23:20-23.

Mattauer, M., 1973. Lés Deformations des Matériaux de l'Ecorce Terrestre: Paris, (Hermann, Collection Méthode).

Profett, J. M., 1977. Cenozoic Geology of the Yerington District, Nevada, and implications for the nature and origin of basin and range faulting. Bull. Geol. Soc. Am., 88:247-260.

Uyeda, S., Hussong, D. M., et al., 1978. General results of DSDP Leg 60 , the eastern portion of the South Philippine Sea transect along $18^{\circ}$ N. Trans. Am. Geophys. Union, 59:1179. (Abstract)

von Huene, R., Nasu, N., et al., 1978. On Leg 57, Japan Trench transected. Geotimes, 23:16-20. 


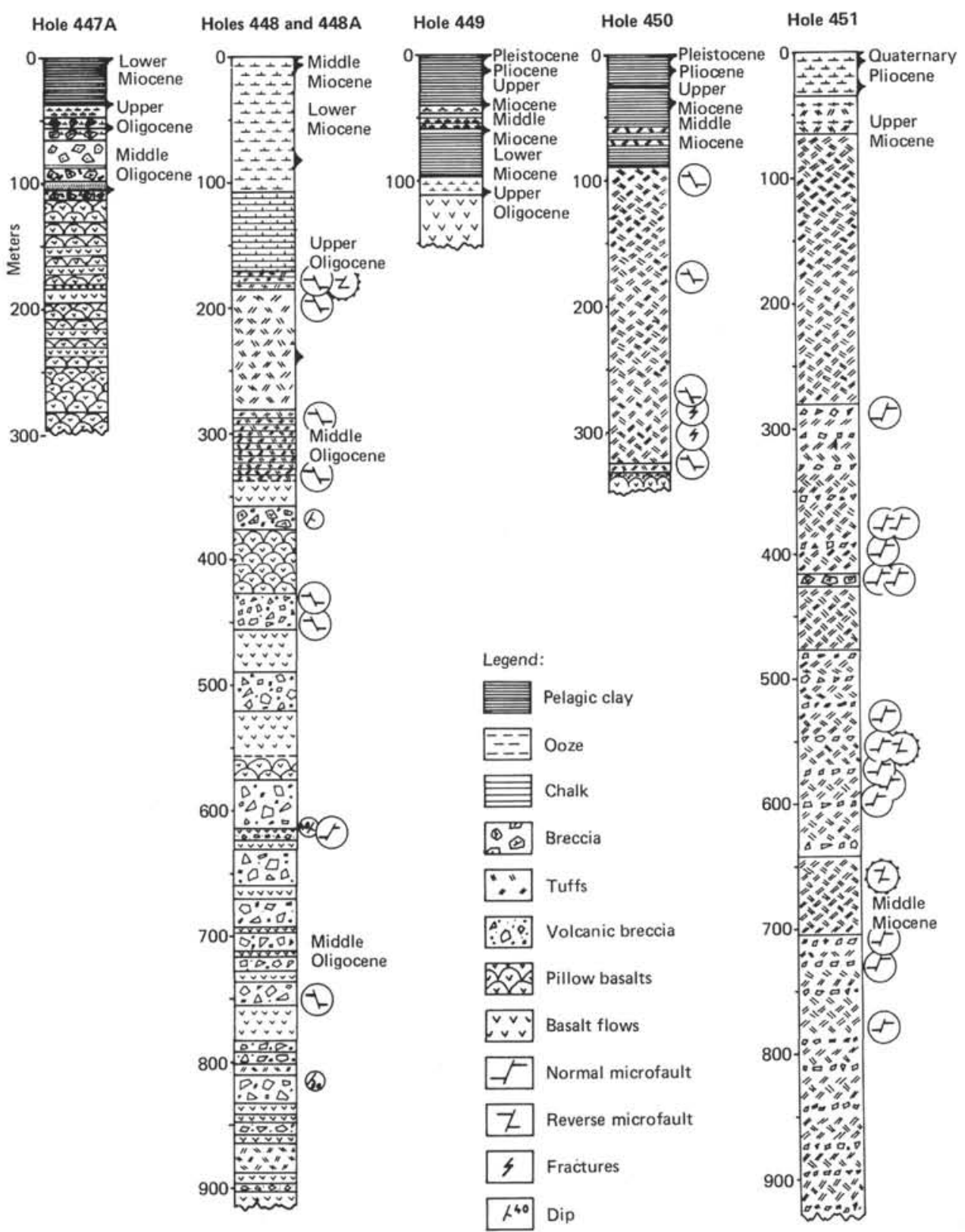

Figure 3. Stratigraphic occurrences of microstructures observed in Leg 59 samples. 
P. CHOTIN

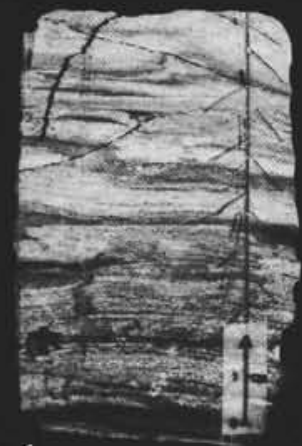

1

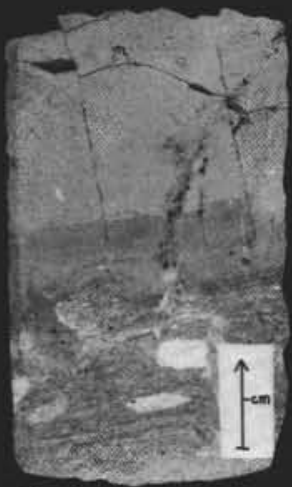

4
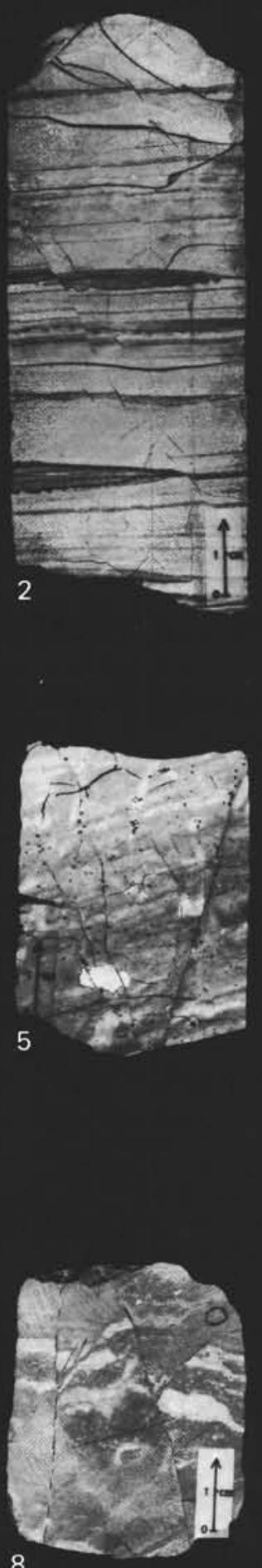
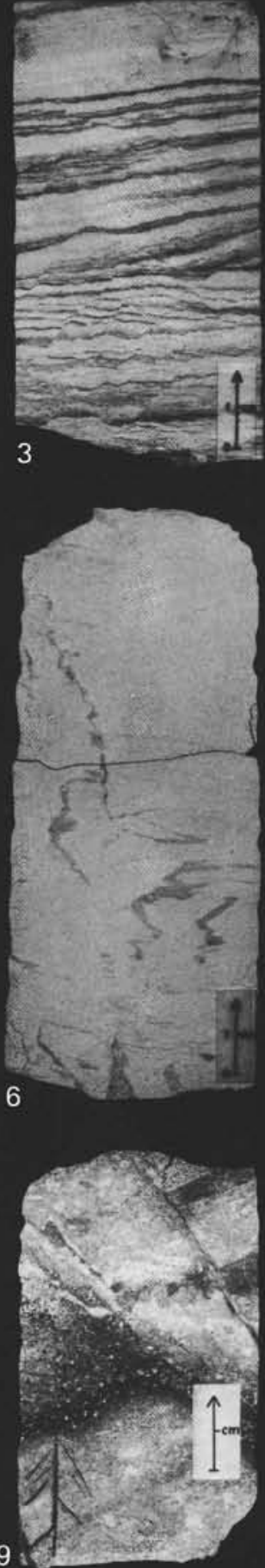

Plate 1. Photographs of microstructures in samples from Leg 59.

Figure 1. Sample 448-19,CC (19-28 cm).

Figure 2. Sample 448-21,CC (3-18 cm).

Figure 3. Sample 448-25-1, 109-120 cm.

Figure 4. Sample 448-29-1, 45-52 cm.
Figure 5. Sample 448-35-1, 18-26 cm.

Figure 6. Sample 450-32-1, 15-29 cm.

Figure 7. Sample 451-31-1, 55-60 cm.

Figure 8. Sample 451-31,CC (14-22 cm).

Figure 9. Sample 451-63-4, 70-81 cm. 